\title{
Nitrogen utilisation by dairy cows fed diets differing in crude protein level with a deficit in ruminal fermentable nitrogen
}

\author{
Valérie Monteils, Stefan JurJanZ*, Gérard Blanchart, \\ François LAURENT \\ Laboratoire de Sciences Animales, INRA-ENSAIA, 2 avenue de la Forêt de Haye, BP 172, \\ 54505 Vandœuvre-lès-Nancy Cedex, France
}

(Received 27 March 2002; accepted 2 October 2002)

\begin{abstract}
We studied the efficiency of nitrogen utilisation by dairy cows, using three diets differing in the crude protein $(\mathrm{CP})$ level but with similar deficits $\left(10 \mathrm{~g} \cdot \mathrm{kg}^{-1}\right.$ dry matter, DM) in ruminal fermentable nitrogen. There was no difference in milk yield from the cows offered the three diets (130, 145 and $\left.160 \mathrm{~g} \mathrm{CP} \cdot \mathrm{kg}^{-1} \mathrm{DM}\right)$. The milk protein content differed between the two most extreme diets ( 28.9 vs. $\left.29.9 \mathrm{~g} \cdot \mathrm{kg}^{-1}, P<0.05\right)$, resulting in higher protein yields for the highest $\mathrm{CP}$ treatment $(P<0.01)$. The efficiency of nitrogen utilisation, calculated as the proportion of ingested nitrogen recovered in the milk, was significantly higher for the $130 \mathrm{~g} \mathrm{CP} \cdot \mathrm{kg}^{-1} \mathrm{DM}$ diet than for the other two diets ( 0.37 vs. 0.33 and 0.32 respectively, $P<0.01$ ). The different diets also resulted in different levels of nitrogen excretion into the environment $\left(237,270\right.$ and $\left.330 \mathrm{~g} \mathrm{~N} \cdot \mathrm{d}^{-1}, P<0.01\right)$. Hepatic deamination of the amino acids may have generated additional energy to enable the animal to make use of the additional nitrogen in the diet, resulting in an increase in plasma urea concentration.
\end{abstract}

nitrogen balance / dairy cow / utilisation / milk / urine

\section{INTRODUCTION}

Improvements in the management of effluents from animal production systems have been recommended to limit environmental damage. Some of the nitrogen excreted by ruminants is of endogenous origin (metabolic losses) and some corresponds to dietary nitrogen (undigested or unused nitrogen). These losses of dietary nitrogen could be reduced by increasing the efficiency of dietary nitrogen use. However,

* Correspondence and reprints

E-mail: jurjanz@ensaia.inpl-nancy.fr 
the impact of decreased nitrogen supply on milk production and on nitrogen release into the environment (urinary + faecal nitrogen) must be assessed.

The improvements in the efficiency of nitrogen use could be obtained in several ways. For example, minor shortages of fermentable nitrogen are tolerated in the rumen $[18,27]$. If the deficit is less than $10 \mathrm{~g} \cdot \mathrm{kg}^{-1}$ $\mathrm{DM}$, this deficit can be compensated by an increase in urea recycling $[18,19]$, and may not result in a decrease in milk yield [6]. Thus, such a deficit could be used to decrease the excretion of nitrogen in the form of urea. The animal could also increase its nitrogen use efficiency by decreasing the amino acid catabolism. Finally, the digestibility of nitrogen in the digestive tract is fairly constant but tends to decrease as the nitrogen content of the diet decreases [7].

This work focuses on the efficiency of nitrogen utilisation by dairy cows. We studied the distribution of feed nitrogen in milk, urine and faeces, to determine the best balance between the production and environmental nitrogen loads. All total mixed rations resulted in the same imbalance between rumen fermentable nitrogen and rumen fermentable energy. We tested three diets differing in the amount of nitrogen supplied, due to differences in the amount of rumen-undegradable protein in the diet.

\section{MATERIALS AND METHODS}

\subsection{Animals and experimental design}

Nine Holstein dairy cows, including 3 primiparous cows, were used in a $3 x$ 3 Latin square design experiment. They were housed in a free-stall barn except during urine sampling. Three multiparous cows were fitted with rumen cannulae (\# $3 \mathrm{C}$, Bar Diamond Inc., Idaho, USA) according to the General Guidelines of the Council of the European Communities (1986, No: $86 / 609 / C E E)$. The factor studied was the amount of nitrogen in the diet $(130,145$ or $160 \mathrm{~g}$ of crude protein $\cdot \mathrm{kg}^{-1}$ of dry matter, $\left.\mathrm{g} \mathrm{CP} \cdot \mathrm{kg}^{-1} \mathrm{DM}\right)$. Each period lasted 3 weeks: two weeks for the adaptation of the cows to their diet and one for measurements and samplings.

At the start of the trial, the cows were a mean of $66 \pm 33$ days into lactation. In average, the food intake was $18.2 \pm 2.2 \mathrm{~kg}$ $\mathrm{DM} \cdot \mathrm{d}^{-1}$, the live weight was $631 \pm 63 \mathrm{~kg}$ and the milk yield was $31.4 \pm 5.7 \mathrm{~kg} \cdot \mathrm{d}^{-1}$.

\subsection{Feeding}

The total mixed ration (TMR), provided ad libitum, consisted of a mixture of grass and maize silages (60:40 in DM), mixed meal (soybean and rapeseed 80:20 in DM) treated with formaldehyde, cracked maize and minerals. The composition of the diets was determined on the basis of the PDI (protein digestible in the intestine) system [28]. This system is based on the concept of metabolisable proteins, corresponding to the amount of amino acids available in the intestine. These amino acids are produced from microbial protein (PDIM) and rumen undegraded feed protein (PDIA). The PDI system takes into account the availability of energy and nitrogen for rumen microbes. Consequently, the PDIME (microbial protein digested in the intestine when rumen fermentable energy is limiting) and the PDIMN (microbial protein digested in the intestine when rumen fermentable nitrogen is limiting) are characterised separately. The PDIE (protein digested in the intestine when rumen fermentable energy is limiting) is the sum of PDIME and PDIA, and the PDIN (protein digested in the intestine when rumen fermentable nitrogen is limiting) is the sum of PDIMN and PDIA. The PDI system recommends similar supplies of PDIME and PDIMN to have a diet balanced for the microbial requirements of nitrogen. However, an increase in urea recycling can compensate for the deficits in fermentable nitrogen of up to $18 \mathrm{~g}$ PDIMN per unit of energy for lactation (UFL) [18] with $1 \mathrm{UFL}=1700 \mathrm{kcal}$ of net energy for lactation, as described by 
Vermorel [29]. Therefore, a systematic nitrogen deficit of $10 \mathrm{~g}$ dPDI (i.e. PDIE - PDIN) was included in all treatments to optimise urea recycling (Tab. I). All diets were isoenergetic: $0.90 \mathrm{UFL} \cdot \mathrm{kg}^{-1} \mathrm{DM}$, corrected for feedstuff interactions as described by Vermorel et al. [30]. Table I presents the compositions and nutritional values of the three diets as well as the recovery rate of microbial nitrogen requirements calculated with the recommendation of the PDI system.

Access to feed was monitored by electronic gates (SEFER, Neuville de Poitou, France): each cow was fitted with a transponder providing access to a single gate. For each period, the individual intake was recorded daily after the first week. The DM $\left(48 \mathrm{~h}\right.$ at $\left.80^{\circ} \mathrm{C}\right)$, crude protein (Kjedahl method), crude fibre (Weende method), $2 \mathrm{~N} \mathrm{HCl}$-insoluble ash [25] and total ash contents $\left(6 \mathrm{~h}\right.$ at $\left.550{ }^{\circ} \mathrm{C}\right)$ were determined for each feed, during each experimental period. Energy and PDI values were calculated as described by Jarrige [11].

\subsection{Characterisation of the diets}

We checked that the diets were similarly digestible in the rumen by carrying out a

Table I. Composition and nutritional values of the diets.

\begin{tabular}{|c|c|c|c|}
\hline Treatment $\left(\mathrm{g} \mathrm{CP} \cdot \mathrm{kg}^{-1} \mathrm{DM}\right)$ & 130 & 145 & 160 \\
\hline $\mathrm{DM}$ of diets $\left(\mathrm{g} \cdot \mathrm{kg}^{-1}\right)$ & 340 & 350 & 360 \\
\hline $\begin{array}{l}\text { Composition of the diets }\left(\mathrm{g} \cdot \mathrm{kg}^{-1} \mathrm{DM}\right) \\
\text { Grass silage } \\
\text { Maize silage } \\
\text { Mixed meal }(80 \% \text { soybean, } 20 \% \text { rapeseed })^{1} \\
\text { Cracked maize } \\
\text { Minerals } \\
\text { Concentrates }\left(\mathrm{g} \cdot \mathrm{kg}^{-1} \mathrm{DM}\right)\end{array}$ & $\begin{array}{r}430 \\
310 \\
90 \\
170 \\
10 \\
260\end{array}$ & $\begin{array}{r}400 \\
280 \\
130 \\
180 \\
10 \\
310\end{array}$ & $\begin{array}{r}380 \\
270 \\
170 \\
170 \\
10 \\
340\end{array}$ \\
\hline $\begin{array}{l}\text { Nutritional values }\left(\mathrm{kg}^{-1} \mathrm{DM}\right) \\
\mathrm{CP}(\mathrm{g}) \\
\operatorname{PDIE}^{3}(\mathrm{~g}) \\
\operatorname{PDIN}^{3}(\mathrm{~g}) \\
\text { PDIA }^{4}(\mathrm{~g}) \\
\text { PDIME }^{5}(\mathrm{~g}) \\
\operatorname{PDIMN}^{5}(\mathrm{~g}) \\
\text { UFL }^{6} \\
\text { NDF }(\mathrm{g}) \\
\text { Ash }(\mathrm{g})\end{array}$ & $\begin{array}{r}130 \\
100 \\
89 \\
49 \\
51 \\
40 \\
0.89 \\
460 \\
74\end{array}$ & $\begin{array}{r}147 \\
114 \\
104 \\
63 \\
51 \\
41 \\
0.90 \\
439 \\
72\end{array}$ & $\begin{array}{r}163 \\
125 \\
117 \\
74 \\
51 \\
43 \\
0.90 \\
430 \\
72\end{array}$ \\
\hline Satisfying rate of microbial $\mathrm{N}$ requirements $(\%)^{7}$ & 78 & 80 & 84 \\
\hline
\end{tabular}

${ }^{1}$ Mixed meal treated with formaldehyde.

${ }^{2}$ Premix contained 6\% P, $24 \%$ Ca, $1 \%$ Na, $5 \% \mathrm{Mg}, 1 \%$ S, $0.38 \% \mathrm{Zn}, 0.25 \% \mathrm{Mn}, 0.1 \% \mathrm{Cu}, 0.006 \% \mathrm{I}, 0.003 \%$ Co and $0.001 \% \mathrm{Se}$.

${ }^{3}$ PDIE, PDIN: proteins digestible in the intestine when rumen fermentable energy or nitrogen, respectively, are limiting [28].

${ }^{4}$ PDIA: rumen escape proteins digestible in the intestine [28].

5 PDIME, PDIMN: microbial protein digested in the intestine when rumen fermentable energy or nitrogen is limiting [28].

${ }^{6}$ UFL: net energy lactation corrected for feeding interaction as described by Vermorel et al. [30].

${ }^{7}$ Satisfying rate calculated with the ratio between the supply of degradable $\mathrm{N} \cdot \mathrm{kg}^{-1} \mathrm{FOM}$ by the three diets and the supply supposed by the PDI system with a balanced diet [28]. 

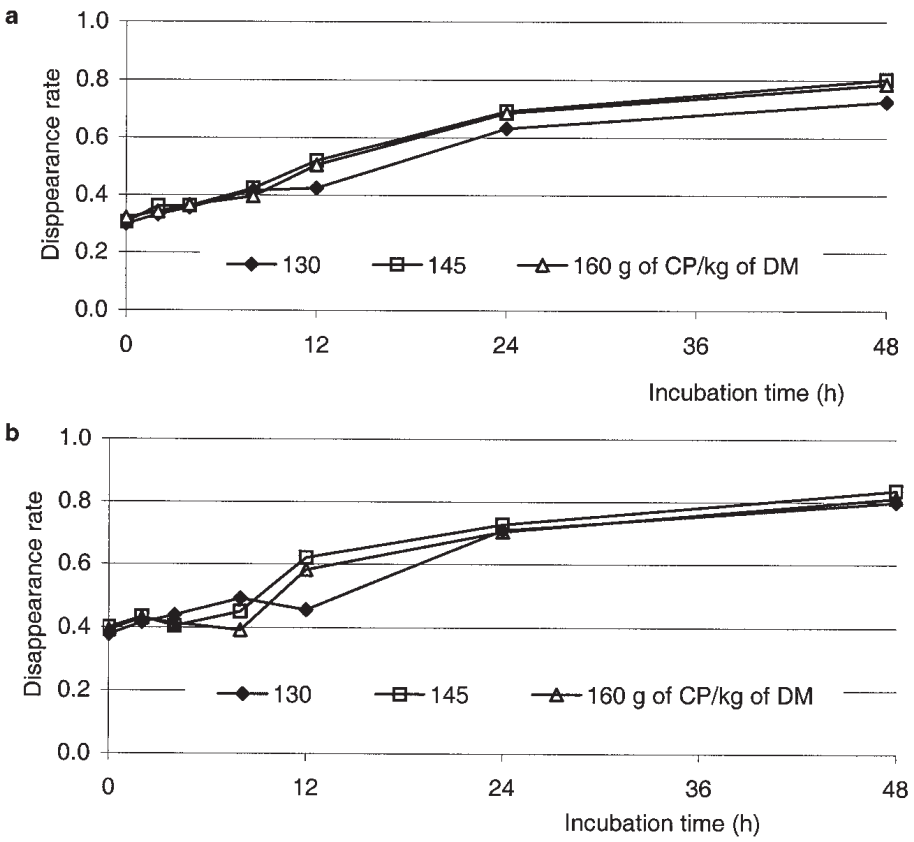

Figure 1. Rates of disappearance of organic matter (a) and crude protein (b) fractions of the three diets in the nylon bag test.

study on cows fitted with rumen cannulae. This study included a trial using the nylon bag technique and the measurement of fermentation parameters after feeding.

The nylon bag technique [16] was used to measure the rate of disappearance of organic matter and $\mathrm{CP}$ from the various diets in the rumen. We placed $4 \mathrm{~g}$ of each diet, made up from individual feedstuffs dried for $48 \mathrm{~h}$ at $60{ }^{\circ} \mathrm{C}$ and ground through a $1.5 \mathrm{~mm}$ sieve, in a $9 \times 14 \mathrm{~cm}$ bag with a pore size of 50 um (Blutex 120, Saati France, Sailly Saillisel, France). Each diet was tested in a cow fed the same diet. The bags were soaked in water and then incubated in the rumen for 2 , 4, 8, 12, 24 and $48 \mathrm{~h}$ (9 replicates each time). The animals were provided with access to feed just after the bags had been put in place. After the incubation, the bags were machinewashed, with two washes for 5 min each in cold water to eliminate the solid particles without supplementary solubilisation. The soluble fraction was taken as the difference between the feed in the bag before incubation and the result of washing in a machine for $2 \times 5 \mathrm{~min}$ in warm water $\left(40^{\circ} \mathrm{C}\right)$, called "time 0". After washing, all the bags were frozen, freeze-dried and the resulting powder was weighed. We pooled all the residues of each diet, for each incubation time, for analysis. Disappearances of CP and OM are calculated as suggested by the model of Ørskov and McDonald [17].

The rates of disappearance of the organic matter and $\mathrm{CP}$ fractions of the diets were similar for all treatments at each incubation time (Fig. 1). Rumen degradation features (Tab. II) confirm that the supplying of microbial protein were similar between all diets for the three diets as PDI calculations let one suppose (Tab. I). The fractions a (water soluble) and b (potentially degradable in the rumen) are very close for the $\mathrm{OM}$ on the one hand and for the $\mathrm{CP}$ on the other 
Table II. Ruminal degradation for the three total mixed rations used, as suggested by Ørskov and McDonald [17].

\begin{tabular}{lcccc}
\hline Treatment $\left(\mathrm{g} \mathrm{CP} \cdot \mathrm{kg}^{-1} \mathrm{DM}\right)$ & $\mathrm{a}^{1}$ & $\mathrm{~b}^{2}$ & $\mathrm{c}^{3}$ & $\mathrm{tD}^{4}$ \\
\hline Disappearance of CP & & & & \\
$\quad 130$ & 37.4 & 65.9 & 2.3 & 55.7 \\
145 & 37.1 & 58.1 & 3.6 & 58.9 \\
160 & 36.8 & 63.1 & 2.7 & 56.4 \\
Disappearance of OM & & & & \\
130 & 29.2 & 58.0 & 3.0 & 48.5 \\
145 & 29.6 & 61.9 & 3.7 & 53.2 \\
160 & 29.7 & 62.7 & 3.4 & 52.4 \\
\hline
\end{tabular}

${ }^{1}$ Water soluble fraction $(\%)$.

${ }^{2}$ Potentially degradable fraction $(\%)$.

${ }^{3}$ Fractional rate of degradation $(\% / \mathrm{h})$.

4 Theoretic degradability $(\%)$.

hand. So, the differences in the protein supply between the diets were mainly due to variable PDIA proportions.

The fermentation of the diets was assessed by a kinetic study on rumen-cannulated cows in a $3 \times 3$ Latin square design, as previously described for other variables. After adaptation, the rumen fluid was sampled a fixed time interval after feeding, using an inflexible probe fed through the rumen cannula. The first rumen fluid sample was taken in the morning before access to feed (time 0 ), and further samples were then taken $0.5,1,2,4,6$, and $8 \mathrm{~h}$ after feeding. The $\mathrm{pH}$ value of the rumen fluid was determined just after sampling (Knick Portamess $n^{\circ} 751$, electrode Xerolyt Ingold $n^{\circ}$ M6-DXK $\mathrm{S} 7 / 25$ ). The liquid phase was separated from the solid particles by centrifugation $(4000 \mathrm{~g}$, $20 \mathrm{~min}$ ) and was immediately frozen. The sample was later thawed and ammonia (electrode 9512, ORION Res. Inc., Boston MA, USA) and volatile fatty acid [12] concentrations were determined.

For all the diets, the rumen $\mathrm{pH}$ values generally remained over 6.0 during the $8 \mathrm{~h}$ after feeding (Tab. III). The mean $\mathrm{pH}$ values recorded with the diet containing $160 \mathrm{~g}$ $\mathrm{CP} \cdot \mathrm{kg}^{-1} \mathrm{DM}$ were lower than those recorded for the other two diets $(P<0.01)$. Post- prandial decreases in $\mathrm{pH}$ between time 0 and 1 hour were similar for the 3 treatments. Mean rumen ammonia concentration was similar for the 3 diets (Tab. III). At time 0, the concentration of $\mathrm{NH}_{3}$ concentration was close to $4 \mathrm{mmol} \cdot \mathrm{L}^{-1}$. It increased after feeding, reaching a peak two hours after access to feed ( 14 to $16 \mathrm{mmol} \cdot \mathrm{L}^{-1}$ ). No significant difference was observed between the treatments in total VFA concentration (NS, Tab. III). The differences were observed between treatments in terms of the molar percentages of acetate and butyrate, but these differences were small (less than 3 percentage points between treatments on average) and changes in the VFA profiles were similar for all the diets.

Ruminal degradation of organic matter and the crude protein fractions of the diets were found to be similar for all three treatments. It is therefore reasonable to assume that the main differences between the treatments were due to differences in the supply of rumen undegradable proteins.

\subsection{Apparent digestibility}

The determination of the apparent digestibility of nitrogen required an estimate of the amount of nitrogen excreted 


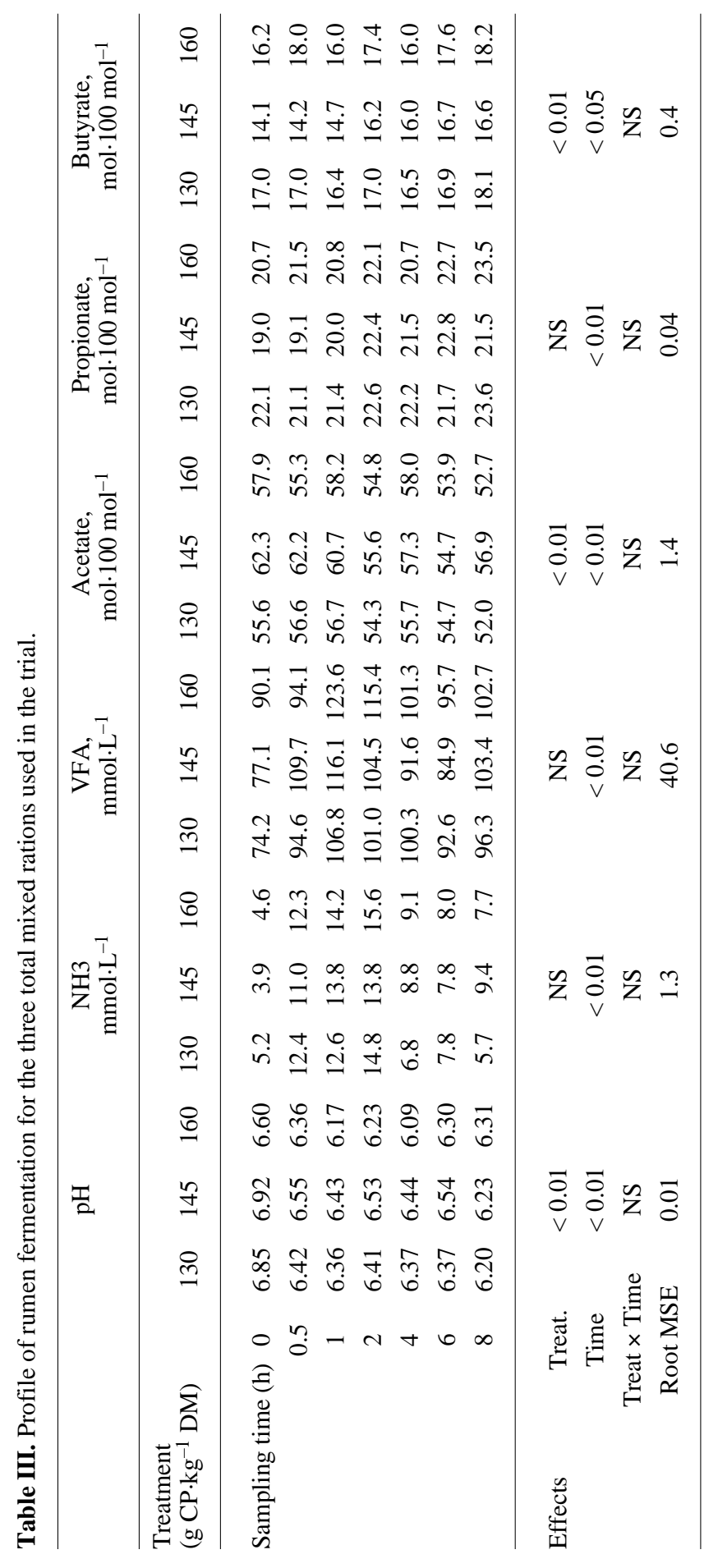


in the faeces. An internal marker was used to estimate the amount of DM excreted in the faeces. Thonney et al. [21] and Block et al. [2] demonstrated that DM excretion is accurately assessed using an internal marker of $2 \mathrm{~N}$ acid-insoluble ash, determined as described by Van Keulen and Young [25] During the third week of each period, faecal samples were collected individually. Sampling was carried out after two weeks of feeding with the same diet, and it is therefore reasonable to assume that the cows were in a state of homeostasis. The samples (500 g) were taken from one defecation in the morning and another in the evening, for two consecutive days. These samples were immediately frozen. They were then freeze-dried, ground (1.5 mm sieve) and the sub samples were pooled for the individual cows and individual diets.

We also analysed the feed offered to and left by each cow the day before and on the same days as faecal sampling. These samples were used to correct for potential feed selection by the cows, as described by Block et al. [12]. They were oven-dried (48 $\mathrm{h}$ at $65^{\circ} \mathrm{C}$ ) and then treated in the same way as the faecal samples.

We estimated the amount of dry matter excreted in the faeces by the cows as follows:

$\underset{\left(\mathrm{kg} \mathrm{DM} \cdot \mathrm{d}^{-1}\right)}{\mathrm{DM} \text { faecal }}=\frac{\text { insoluble ash intake }\left(\mathrm{g} \cdot \mathrm{d}^{-1}\right)}{\text { insoluble ash ces content }}$ in faeces $\left(\mathrm{g} \cdot \mathrm{kg}^{-1} \mathrm{DM}\right)$

The amounts of nitrogen in the faeces and in the feed left by the cows were determined from the pooled samples.

\subsection{Plasma urea concentration}

Blood samples were taken on two consecutive days from the caudal vein of each cow, 4.5 hours after the cow was first provided with access to feed. The plasma was immediately isolated by centrifugation (3000 g, $10 \mathrm{~min}$ ) and frozen. Plasma urea concentration was determined by colorimetry (Kit UR 222, Randox, Montpellier, France).

\subsection{Milk yield and composition}

Milk yield was recorded automatically for each individual cow at each milking (Isalait System 2045, Boumatic, France). Milk samples were taken from 4 consecutive milkings during week 3 of each period. The fat and protein contents of the milk were determined for each sample by infra-red spectrometry analysis (MILKOSCAN, Fossomatic, DK). The total nitrogen content and the non-protein nitrogen content [20] of milk samples were determined using the Kjeldahl method taking into account the yield of milk over a 24-h period. The urea concentration of the milk was determined as described by Siest [23].

\subsection{Urine}

Total urine production was collected from each cow over a period of 48 consecutive hours at the end of week 3 . All the cows were attached in free-standing stalls by means of collars to facilitate this process. Urine was collected using probes (SIMS Portex Limited, Kent, England, Ref 41-515-42) linked to cans, each can containing $200 \mathrm{~mL}$ of $30 \%$ sulphuric acid. The urine collected was weighed every 12 hours, and a sample was then frozen. The total nitrogen content of the urine samples was determined (Kjeldahl method) after filtration and the dilution of the samples 1:20 with water. Urea concentration was determined in the samples diluted $1: 250$ [23].

\subsection{Data processing}

Rumen digestion variables were analysed by analysis of variance (GLM procedure, SAS Inst., Inc., Cary, NC, USA) with the repeated time option. The model used took into account the fixed factor treatment and sampling time, and their interaction. The block factor could therefore be ignored but the random cow factor was retained in the analysis. The covariance structure between 
the different sampling times was found to be auto-regressive after checking the criteria of Akaike and Schwarz-Bayesian [15].

All data were averaged over the measurement week. A difference of one or two days in the time at which the variables were recorded is acceptable since a state of homeostasis should have been reached by this time.

The data were processed by analysis of variance, using the GLM procedure of SAS (SAS Inst., Inc., Cary, NC, USA). The model used took into account the factors treatment, period and block. The hierarchical factor cow by block, and the factors block and period were randomised.

The variables analysed for the three treatments are presented as least squares means (i.e. adjusted for the effects of the other factors in the model) and were compared by means of the Student $t$-test. Significance was declared at $\mathrm{P}$ values less than 0.05 using the error of the sum of squares (type III).

\section{RESULTS AND DISCUSSION}

Daily DM (17.1, 17.6 and $18.6 \mathrm{~kg} \mathrm{DM})$ and energy (15.0, 15.5 and 16.3 UFL) intakes did not differ between the diets containing 130, 145 and $160 \mathrm{~g} \mathrm{CP} \cdot \mathrm{kg}^{-1} \mathrm{DM}$ respectively, although the absolute figures obtained tended to increase with the $\mathrm{CP}$ content of the diet. Nitrogen intake varied significantly $(P<0.01)$, from 359 to 420 to $483 \mathrm{~g} \cdot \mathrm{d}^{-1}$, with increasing dietary CP levels.
Since no difference was observed in the degradability of the three diets in the rumen, and there was no difference in DM intake, the differences in nitrogen intake presumably resulted in a difference in the escape of the proteins from the rumen.

Mean milk yield was not significantly affected by the treatment (Tab. IV), although in absolute terms, the cows fed the $160 \mathrm{~g}$ $\mathrm{CP} \cdot \mathrm{kg}^{-1} \mathrm{DM}$ diet produced $2 \mathrm{~kg}$ more milk than those fed the $130 \mathrm{~g} \mathrm{CP} \cdot \mathrm{kg}^{-1} \mathrm{DM}$ diet. This is quite a large difference but it was not significant due to the high level of variability between the cows. Milk protein content was significantly higher for the $160 \mathrm{~g} \mathrm{CP} \cdot \mathrm{kg}^{-1} \mathrm{DM}$ treatment than for the $130 \mathrm{~g} \mathrm{CP} \cdot \mathrm{kg}^{-1} \mathrm{DM}$ treatment (Tab. IV). Protein yields were 880 , 914 and $989 \mathrm{~g} \cdot \mathrm{d}^{-1}$ for the three diets, in an ascending order of crude protein content, and the value of the $160 \mathrm{~g} \mathrm{CP} \cdot \mathrm{kg}^{-1} \mathrm{DM}$ treatment was significantly higher than those of the other treatments $(P<0.01)$. The fat content of the milk was similar for all treatments. Total fat yield (1233, 1289 and $1402 \mathrm{~g} \cdot \mathrm{d}^{-1}$ respectively) increased with crude protein content of the diet, with the cows offered the $160 \mathrm{~g} \mathrm{CP} \cdot \mathrm{kg}^{-1}$ diet giving a significantly higher fat yield than the cows offered the other diets $(P<0.01)$. In this trial, milk protein content was not very high. Milk protein content is highly correlated with energy supply, so the low milk protein contents obtained may reflect the inability of these three diets to meet the energy requirements ( $85 \%$ of energy requirements met).

Table IV. Milk yield and composition.

\begin{tabular}{|c|c|c|c|c|c|}
\hline $\begin{array}{l}\text { Treatment } \\
\left(\mathrm{g} \mathrm{CP} \cdot \mathrm{kg}^{-1} \mathrm{DM}\right)\end{array}$ & 130 & 145 & 160 & Treatment effect & Root MSE \\
\hline Milk yield $\left(\mathrm{kg} \cdot \mathrm{d}^{-1}\right)$ & 30.7 & 30.8 & 32.7 & NS & 2.7 \\
\hline Protein content $\left(\mathrm{g} \cdot \mathrm{kg}^{-1}\right)$ & $28.9^{\mathrm{b}}$ & $29.5^{\mathrm{ab}}$ & $29.9^{\mathrm{a}}$ & $<0.05$ & 0.7 \\
\hline Fat content $\left(\mathrm{g} \cdot \mathrm{kg}^{-1}\right)$ & 40.0 & 41.1 & 41.8 & NS & 1.8 \\
\hline Total nitrogen in milk $\left(\mathrm{g} \cdot \mathrm{d}^{-1}\right)$ & $138^{\mathrm{b}}$ & $143^{\mathrm{b}}$ & $158^{\mathrm{a}}$ & $<0.01$ & 10 \\
\hline Nitrogen in milk proteins $\left(\mathrm{g} \cdot \mathrm{d}^{-1}\right)$ & $131^{\mathrm{b}}$ & $135^{\mathrm{b}}$ & $149^{\mathrm{a}}$ & $<0.01$ & 9 \\
\hline Milk NPN $\left(g \cdot d^{-1}\right)$ & $7.6^{\mathrm{b}}$ & $7.9^{\mathrm{b}}$ & $9.4^{\mathrm{a}}$ & $<0.01$ & 0.9 \\
\hline
\end{tabular}

a,b,c Means with different superscripts in the same row are significantly different $(P>0.05)$. 
The amounts of nitrogen recovered in the milk, in milk proteins and in the nonprotein fraction (NPN) of milk were similar for the 130 and $145 \mathrm{~g} \mathrm{CP} \cdot \mathrm{kg}^{-1} \mathrm{DM}$ treatments (Tab. IV), and were significantly lower for these two treatments than for the $160 \mathrm{~g} \mathrm{CP} \cdot \mathrm{kg}^{-1} \mathrm{DM}$ treatment $(P<0.01)$. The proportions of nitrogen ingested that were recovered in the milk were $0.37,0.33$ and 0.32 for the three treatments, in ascending order of crude protein content. A significantly higher proportion of nitrogen was obtained in the milk for the $130 \mathrm{~g} \mathrm{CP} \cdot \mathrm{kg}^{-1}$ DM diet compared to the other two diets $(P<0.01)$. The efficiency of utilisation of feed nitrogen for milk production observed was important and especially for the $130 \mathrm{~g}$ $\mathrm{CP} \cdot \mathrm{kg}^{-1} \mathrm{DM}$ treatment. These high levels of nitrogen secretion in the milk represent a great interest for decreasing nitrogen excretion in the environment (faeces and urine). Many trials have recently studied the utilisation of feed nitrogen by dairy cows; the values observed are from 0.24 to 0.30 of nitrogen ingested recovered in milk by Castillo et al. [4, 5]; from 0.29 to 0.33 by Fisher et al. [10] and from 0.25 to 0.34 by Kebreab et al. [13]. In these trials, the levels of crude protein in the diets were between $12.3 \% \mathrm{DM}$ and $19.0 \%$ but no indication of the energy supplies were available. So, it is difficult to explain the differences of utilisation with our results. The use of mixed grass and maize silages could be an explanation because the energetic density of the diets was increased; this was not the case for Castillo et al. [4, 5] and Kebreab et al. [13].
The increase of CP content in the diet had a great impact (a sharp increase) on the amounts of nitrogen excreted into the environment via urine $(P<0.01$, Tab. V). Consecutive levels of treatment differed by 30 to $40 \mathrm{~g} \cdot \mathrm{d}^{-1}$. The significant differences in urinary nitrogen excretion were observed between the three diets. Smaller differences were observed between the treatments for faecal nitrogen excretion (a difference of $22 \mathrm{~g} \cdot \mathrm{d}^{-1}$ at the most). The $160 \mathrm{~g} \mathrm{CP} \cdot \mathrm{kg}^{-1}$ DM treatment resulted in a higher level of nitrogen excretion in the faeces than did the other treatments $(P<0.01)$. The total amounts of nitrogen excreted into the environment were estimated to be 237,270 and $330 \mathrm{~g} \cdot \mathrm{d}^{-1}$ for the 130,145 and $160 \mathrm{CP} \cdot \mathrm{kg}^{-1}$ DM diets respectively $(P<0.01)$, corresponding to the proportions of $0.64,0.63$ and 0.67 of ingested nitrogen, respectively (NS). The nitrogen digestibility calculated with these results was similar for the 145 and $160 \mathrm{~g} \mathrm{CP} \cdot \mathrm{kg}^{-1} \mathrm{DM}$ diets $(0.71$ and 0.70 respectively) but significantly lower for the $130 \mathrm{~g} \mathrm{CP} \cdot \mathrm{kg}^{-1} \mathrm{DM} \operatorname{diet}(0.67, P<0.01)$.

Previous studies of nitrogen distribution $[8,18,26]$ have reported a tendency for the apparent digestibility of nitrogen to increase with dietary nitrogen level. Wright et al. [32], in a study on cows under restricted feeding conditions $(-10$ or $-20 \%)$, also reported significant variations. Spanghero and Kowalski [24], showed that in the data of 14 trials, $94 \%$ of the deviation of digestible nitrogen levels could be accounted for by the deviation of nitrogen intake. Thus, the amount of apparently digested nitrogen

Table V. Excretion of nitrogen into the environment.

\begin{tabular}{lccccc}
\hline $\begin{array}{l}\text { Treatment } \\
\left(\mathrm{g} \mathrm{CP} \cdot \mathrm{kg}^{-1} \mathrm{DM}\right)\end{array}$ & 130 & 145 & 160 & Treatment effect & Root MSE \\
\hline Urinary nitrogen $\left(\mathrm{g} \cdot \mathrm{d}^{-1}\right)$ & $117^{\mathrm{c}}$ & $147^{\mathrm{b}}$ & $185^{\mathrm{a}}$ & $<0.01$ & 16 \\
Faecal nitrogen $\left(\mathrm{g} \cdot \mathrm{d}^{-1}\right)$ & $120^{\mathrm{b}}$ & $123^{\mathrm{b}}$ & $145^{\mathrm{a}}$ & $<0.01$ & 15 \\
\hline
\end{tabular}

a,b,c Means with different superscripts in the same row are significantly different $(P>0.05)$. 
increases with nitrogen intake. The differences in the amounts of nitrogen ingested or apparently digested between the different diets were greater than the differences in the amounts of protein recovered in the milk. This was shown by a decrease in the ratio of nitrogen in milk proteins to ingested nitrogen with increasing CP levels in the diet, confirming the results of Castillo et al. [5], Dinn et al. [8], Fisher et al. [10], Peyraud et al. [18], Van Vuuren et al. [26], Volden [31] and Wright et al. [32]. Consequently, the amount of nitrogen released in the urine increased with increasing CP supply. The ratio of nitrogen excreted in the urine to ingested nitrogen increases (from 0.35 to 0.46 ) with the degradability of the protein in the concentrate [5]. When this ratio was calculated in previous studies, it was found to increase with increasing CP levels: values from 0.31 to 0.39 were obtained by Dinn et al. [8], from 0.18 to 0.30 by Peyraud et al. [18], and from 0.20 to 0.50 by Wright et al. [32]. These data are consistent with our results concerning urinary excretion, which accounted for 0.32 to 0.37 of ingested nitrogen. Kebreab et al. [14] developed a dynamic model of nitrogen metabolism. They showed that urine nitrogen output has an exponential response to increased levels of nitrogen intake with a coefficient of determination of 0.79 . Protein degradability seems to have a major impact on the urinary excretion of nitrogen. The lowest value $(0.18)$ reported by Peyraud et al. [18] was obtained with a larger deficit of ruminal fermentable nitrogen than that used here $\left(17 \mathrm{~g}\right.$ PDIMN $\cdot \mathrm{kg}^{-1}$
$\mathrm{DM}$ vs. $11 \mathrm{~g}$ at the most). With simulations, the model described by Kebreab et al. [14] showed that energy availability has a major effect on the amount of nitrogen excreted in the urine. This effect is linearly related to an increase in the available energy.

Overall, these results show that an increase in nitrogen intake results in a greater increase in urinary excretion than in faecal excretion or secretion in the milk. These observations were consistent with the conclusions of Spanghero and Kowalski's review [24] that $50 \%$ of the deviation of nitrogen losses in the urine can be accounted for by the deviation of digestible nitrogen intake, whereas only $20 \%$ of the deviation is accounted for by nitrogen levels in the milk. In our trial, no significant difference was observed between the energy intakes for the three diets, however 1.3 UFL less was consumed by the cows offered the $130 \mathrm{~g} \mathrm{CP} \cdot \mathrm{kg}^{-1}$ diet than those offered the $160 \mathrm{~g} \mathrm{CP} \cdot \mathrm{kg}^{-1}$ diet and the ruminal degradation of the organic matter was a little lower for this diet (Fig. 1a). So, in spite of similar rumen ammonia concentrations, the hypothesis of different ammonia absorptions cannot be totally ruled out to explain a part of the different urinary excretion.

Plasma urea concentrations ranged from 3.96 to $5.94 \mathrm{mmol} \cdot \mathrm{L}^{-1}$ (Tab. VI). These values increased significantly $(P<0.01)$ with the dietary nitrogen level. Similar differences between the diets were observed for the amounts of nitrogen present as urea in milk or in urine. The additional nitrogen supplied in the diets with high nitrogen levels

Table VI. Urea distribution between the different compartments.

\begin{tabular}{lrrrrr}
\hline $\begin{array}{l}\text { Treatment } \\
\left(\mathrm{g} \mathrm{CP} \cdot \mathrm{kg}^{-1} \mathrm{DM}\right)\end{array}$ & 130 & 145 & 160 & Treatment effect & Root MSE \\
\hline Plasma urea $\left(\mathrm{mmol} \cdot \mathrm{L}^{-1}\right)$ & $4.0^{\mathrm{c}}$ & $4.7^{\mathrm{b}}$ & $5.9^{\mathrm{a}}$ & $<0.01$ & 0.0 \\
Milk urea N $\left(\mathrm{g} \cdot \mathrm{d}^{-1}\right)$ & $2.8^{\mathrm{c}}$ & $3.5^{\mathrm{b}}$ & $4.8^{\mathrm{a}}$ & $<0.01$ & 0.6 \\
Urine urea N $\left(\mathrm{g} \cdot \mathrm{d}^{-1}\right)$ & $70.5^{\mathrm{c}}$ & $87.4^{\mathrm{b}}$ & $126.6^{\mathrm{a}}$ & $<0.01$ & 17.3 \\
\hline
\end{tabular}

a,b,c Means with different superscripts in the same row are significantly different $(P>0.05)$. 
was used less efficiently than the "basal" nitrogen level supplied by a diet less rich in nitrogen. The lower utilisation efficiency was shown by the differences observed in the blood compartment. Indeed, plasma urea concentrations are an indication of both nitrogen absorption and nitrogen metabolism within the organism, and the pool of circulating urea increased as the amount of $\mathrm{CP}$ increased in the diet. Our observations were consistent with those of Dinn et al. [8], Peyraud et al. [18], Volden [31] and Wright et al. [32]. There are three possible reasons for this effect. Firstly, uraemia may result from a greater $\mathrm{NH}_{3}$ production and absorption in the rumen in cows fed the diet with the highest $\mathrm{CP}$ level, corresponding to a loss of nitrogen in this case. This did not appear likely in our trial, given that rumen ammonia profiles were similar for the various diets. However, a small difference in organic matter ruminal degradation was observed. Its impact cannot be totally excluded even if we consider this as minor. Secondly, urea recycling efficiency may decrease as the dietary nitrogen levels increase. Considering the degradations of the organic matter and crude protein fractions of the diets, we can suggest that the micro-organisms were faced with similar conditions in terms of the satisfaction of nitrogen and energy requirements. So, the level of urea recycling in our experimental conditions was probably similar for the three treatments. A third possibility that may account for the differences in the pool of circulating urea concerns the deamination of some of the amino acids, to compensate for the energy deficit with respect to available nitrogen levels. Although the extent to which the energy requirements were met in the three treatments were similar, this hypothesis remains feasible, because the extent to which nitrogen requirements were covered resulted in a nitrogen surplus in the case of the $145 \mathrm{~g} \mathrm{CP} \cdot \mathrm{kg}^{-1} \mathrm{DM}$ diet $(117 \%)$ and the $160 \mathrm{~g} \mathrm{CP} \cdot \mathrm{kg}^{-1} \mathrm{DM}$ diet $(128 \%)$. In addition, the liver may play a role, detoxifying the excess nitrogen for the organism. According to Peyraud et al. [18], low plasma urea concentrations may result from more efficient urea recycling in cows fed low-nitrogen diets ( $73 \%$ of nitrogen requirements covered). Conversely, Dinn et al. [8] concluded that uraemia increases due to the surplus supply of proteins. In our trial, in the case of the $130 \mathrm{~g} \mathrm{CP} \cdot \mathrm{kg}^{-1} \mathrm{DM}$ treatment, the amount of nitrogen excreted as urea in the urine may be considered representative of all urea losses, whether ruminal or due to the "minimal" deamination of amino acids in the liver to produce energy. The 145 and $160 \mathrm{~g} \mathrm{CP} \cdot \mathrm{kg}^{-1} \mathrm{DM}$ treatments led to additional losses of 17 and $59 \mathrm{~g}$ of nitrogen in the form of urea in the urine, respectively, whereas differences in the amounts of urea obtained in the milk were small. The availabilities of rumen-degraded nitrogen and rumen-degraded energy were deemed similar for all the treatments (urea recycling was limited). The increase of uraemia could be due in part to the additional deamination of amino acids to produce added energy or the elimination of the nitrogen surplus by detoxification, or both. The increase of urinary excretion of nitrogen could be related at least in part to uraemia as Al-Dehneh et al. [1] indicated that $65 \%$ of plasma urea is excreted in the urine. The variations in urea concentration in milk and urine were similar since the ratio of urine urea concentration to milk urea concentration in our trial was constant for the three treatments (between 26 and 28, NS). So, the impact of an increase in urea excretion was stronger in the urine than in the milk. Milk urea is well known as an indicator of the protein-energy balance $[3,9]$ or as an indicator of the rumen-degradable protein balance [22]. Urea excretion by this route accounts for only a small proportion of all excreted nitrogen. An additional deamination phenomenon would release energy, making it possible to use some of the additional nitrogen in the milk proteins. The $160 \mathrm{~g} \mathrm{CP} \cdot \mathrm{kg}^{-1} \mathrm{DM}$ treatment involved a supplementary intake of $0.8 \mathrm{UFL} \cdot \mathrm{d}^{-1}$ and the supplementary valorisation of the nitrogen in milk of about $15 \mathrm{~g} \cdot \mathrm{d}^{-1}$. This release of supplementary energy did not account for the differences in the yield and composition 
of the milk. This observation is consistent with the notion that some amino acids were deaminated to produce energy.

\section{CONCLUSIONS}

In the context of a deficit of fermentable nitrogen in a total mixed ration, the $160 \mathrm{~g}$ $\mathrm{CP} \cdot \mathrm{kg}^{-1} \mathrm{DM}$ diet resulted in the release of larger amounts of nitrogen in the milk, but also into the environment. The proportion of nitrogen ingested and present in the milk was higher for the $130 \mathrm{~g} \mathrm{CP} \cdot \mathrm{kg}^{-1}$ DM treatment. However, the lowest protein concentration treatment result in a lower protein yield in milk, with a marked difference in milk yield. High milk and protein yields seem to be associated with high crude protein level in the diet and high levels of nitrogen excretion into the environment.

The diets studied did not meet the total energy requirements. The available data suggest that there could be an increase in amino acid deamination to supply additional energy to the organism. Supplying various amounts of energy at a given nitrogen level could be an effective way of demonstrating the role of this factor in the distribution of digested nitrogen in milk proteins, milk NPN and urine. The maintenance of nitrogen utilisation efficiency should also be considered.

\section{REFERENCES}

[1] Al-Dehneh A., Huber J.T., Wanderley R., Theurer C.B., Pessarakli M., DeYoung D., Incorporation of recycled urea-N into ruminal bacteria flowing to the small intestine of dairy cows fed a high-grain or high-forage diet, Anim. Feed Sci. Technol. 68 (1997) 327-338.

[2] Block E., Kilmer L.H., Muller L.D., Acid insoluble ash as a marker of digestibility for sheep fed plants or hay and for lactating dairy cattle fed hay ad libitum, J. Anim. Sci. 52 (1981) 1164-1169.

[3] Carlsson J., Pherson B., The influence of the dietary balance between energy and protein on milk urea concentration. Experimental trials assessed by two different protein evaluation systems, Acta Vet. Scand. 35 (1994) 193-205.
[4] Castillo A.R., Kebreab E., Beever D.E., Barbi J.H., Sutton J.D., Kirby H.C., France J., The effect of energy supplementation on nitrogen utilization in lactating dairy cows fed grass silage diets, J. Anim. Sci. 79 (2001) 240-246.

[5] Castillo A.R., Kebreab E., Beever D.E., Barbi J.H., Sutton J.D., Kirby H.C., France J., The effect of protein supplementation on nitrogen utilization in lactating dairy cows fed grass silage diets, J. Anim. Sci. 79 (2001) 247-253.

[6] Colin-Schoellen O., Jurjanz S., Laurent F. Metabolizable protein supply (PDIE) and restricted level of ruminally degradable nitrogen (PDIN) in total mixed rations: effect on milk production and composition and on nitrogen utilization by dairy cows, Livest. Prod. Sci. 67 (2000) 41-53.

[7] Demarquilly C., Chenost M., Giger S., Pertes fécales et digestibilité des aliments et des rations, in: Jarrige R., Ruckebusch Y., Demarquilly C., Farce M.H., Journet M. (Ed.), Nutrition des ruminants domestiques, Ingestion et digestion, INRA, Paris, 1995, pp. 601-647.

[8] Dinn N.E., Shelford J.A., Fisher L.J., Use of the Cornell net carbohydrate and protein system and rumen-protected lysine and methionine to reduce nitrogen excretion from lactating dairy cows, J. Dairy Sci. 81 (1998) 229-237.

[9] Eicher R., Bouchard E., Bigras-Poulin M., Factors affecting milk urea and protein concentrations in Quebec dairy cows, Prev. Vet. Med. 39 (1999) 53-63.

[10] Fisher L.J., Dinn N.E., Shelford D.A., Paul J.W The effect of concentration and form of dietary nitrogen on the utilization and excretion of nitrogen by lactating dairy cows, Can. J. Anim. Sci. 80 (2000) 207-209.

[11] Jarrige R. (Ed.), Alimentation des Bovins, Ovins et Caprins, INRA, Paris, 1988.

[12] Jouany J.P., Volatile fatty acid and alcohol determination in digestive contents, silage juices, bacterial cultures and anaerobic fermentor contents, Sci. Aliments 2 (1982) 131-144.

[13] Kebreab E., Castillo A.R., Beever D.E., Humphries D.J., France J., Effects of management practices prior to and during ensiling and concentrate type on nitrogen utilization in dairy cows, J. Dairy Sci. 83 (2000) 1274-1285.

[14] Kebreab E., France J., Mills J.A.N., Alisson R. Dijkstra J., A dynamic model of N metabolism in the lactating dairy cow and an assessmen of impact of $\mathrm{N}$ excretion on the environment, J. Anim. Sci. 80 (2002) 248-259.

[15] Littell R.C., Milliken G.A., Stroup W.W. Wolfinger R.D., SAS-system for mixed models, SAS Institute Inc., Cary, NC, USA, 1996.

[16] Michalet-Doreau B., Vérité R., Chapoutot P., Méthodologie de mesure de la dégradabilité in sacco de l'azote des aliments dans le rumen, Bull. Tech. CRZV Theix INRA 69 (1987) 5-7. 
[17] Orskov E.R., McDonald I., The estimation of protein degradability in the rumen from incubation measurements weighted according to rate of passage, J. Agric. Sci. 92 (1979) 499-503.

[18] Peyraud J.L., Le Liboux S., Vérité R., Effet du niveau et de la nature de l'azote dégradable sur la digestion ruminale d'un régime à base d'ensilage de maïs chez la vache laitière, Reprod. Nutr. Dev. 37 (1997) 313-328.

[19] Peyraud J.L., Astigarraga L., Faverdin P., Digestion of fresh perennial ryegrass fertilized at two levels of nitrogen by lactating dairy cows, Anim. Feed Sci. Technol. 64 (1997) 155-171.

[20] Rowland S.J., The determination of the nitrogen distribution in milk, J. Dairy Sci. 19 (1938) 42-46.

[21] Thonney M.L., Duhaime D.J., Moe P.W., Reid J.T., Acid insoluble ash and permanganate lignin as indicators to determinate digestibility of cattle rations, J. Anim. Sci. 49 (1979) 1112-1116.

[22] Schepers A.J., Meijer R.G., Evaluation of the utilization of dietary nitrogen by dairy cows based on urea concentration in milk, J. Dairy Sci. 81 (1998) 579-584.

[23] Siest C., Étude de la réaction urée-diacétylmonoxime. II. Essais de divers adjuvants. Choix d'une méthode de dosage, Ann. Biol. Clin. 26 (1968) 431-448.

[24] Spanghero M., Kowalski Z.M., Critical analysis of $\mathrm{N}$ balance experiments with lactating cows, Livest. Prod. Sci. 52 (1997) 113-122.

[25] Van Keulen J., Young B.A., Evaluation of acidinsoluble ash as a natural marker in ruminant digestibility studies, J. Anim. Sci. 44 (1977) 282-287.

[26] Van Vuuren A.M., Van der Koelen C.J., Valk H., De Visser H., Effects of partial replacement of ryegrass by low protein feeds on rumen fermentation and nitrogen loss by dairy cows, J. Dairy Sci. 76 (1993) 2982-2993.

[27] Vérité R., Peyraud J.L., Protein: the PDI system, in: Jarrige R., Libbey J. (Ed.), Ruminan Nutrition: recommended allowances and feed tables, INRA, Paris, 1989, pp. 33-48.

[28] Vérité R., Michalet-Doreau B., Chapoutot P., Peyraud J.L., Poncet C., Révision du système PDI, Bull. Tech. CRZV Theix INRA 70 (1987) 19-34.

[29] Vermorel M., Nutrition énergétique, in: Jarrige R. (Ed.), Alimentation des Bovins, Ovins et Caprins, INRA, Paris, 1988, pp. 75-93.

[30] Vermorel M., Coulon J.B., Journet M., Révision du système des unités fourragères, Bull. Tech. CRZV Theix INRA 70 (1987) 9-18.

[31] Volden H.J., Effects of level of feeding and ruminally undegraded protein on ruminal bacterial protein synthesis, escape of dietary protein, intestinal amino acid profile, and performances of dairy cows, J. Anim. Sci. 77 (1999) 1905-1918.

[32] Wright T.C., Moscardini S., Luimes P.H., Susmel P., Mc Bride B.W., Effects of rumenundegradable protein and feed intake on nitrogen balance and milk protein production in dairy cows, J. Dairy Sci. 81 (1998) 784-793. 